\title{
Effect of Tree Size, Root Pruning, and Production Method on Root Growth and Lateral Stability of Quercus virginiana
}

\author{
Edward F. Gilman and Forrest J. Masters
}

\begin{abstract}
This research aimed to evaluate impact of slicing the outer edge of container root balls, initial tree size at planting, and root ball composition on post-planting tree stability in a simulated wind storm. One-hundred twenty Cathedral Oak ${ }^{\circledR}$ live oak were planted in March 2005 . Thirty field-grown trees were transplanted, and 60 trees of similar size were planted from $170 \mathrm{~L}$ containers. Root ball sides on 30 containers were sliced prior to planting. Thirty smaller trees from $57 \mathrm{~L}$ containers were planted without slicing. Trees were pulled with an electric winch, and blown with a hurricane simulator in 2007. Slicing the root ball had no impact on root growth, bending moment, or bending stress. More bending stress was required to pull field-grown trees than trees planted from containers of either size. Growing trees in containers for three years prior to landscape planting changed root morphology compared to field-grown trees, which corresponded to reduced stability. Trees planted from small containers were as stable as those from larger containers. Root cross-sectional area windward correlated the most with bending stress required to tilt trees with a winch and cable. Bending moment scaled to the 3.4 power of trunk diameter.

Key Words: Bending Stress; Container-Grown; Field-Grown; Root Cross-Sectional Area; Root Diameter; Root Number; Saturated Soil; Trunk Diameter; Wind.
\end{abstract}

Wind causes tree overturning which damages trees, adjacent buildings, and associated structures. Thousands of trees were overturned by hurricanes in the southeastern United States between 1989 and 2004 (Duryea et al. 2007). In at least some cases, the original root ball periphery was clearly evident as young trees lay horizontal on the soil surface. Periphery of root balls were defined by roots deflected by the container wall or branched where roots were cut when transplanted from the field nursery. Causes of root failure in wind are poorly documented for nonconiferous, young shade trees.

Tree size, age, root form, and soil attributes influence stability of well established trees. Nursery production method can also influence tree stability. Most studies were conducted on trees planted from small propagation-sized $(5 \mathrm{~cm}$ diameter) containers used in reforestation. Robert and Lindgren (2006) showed no difference in stability 3 to 10 years after planting lodgepole pine (Pinus contorta Douglas ex Louden) from $5 \mathrm{~cm}$ diameter containers with defective root form compared to naturally regenerated trees. However, naturally regenerated Scots pine (Pinus sylvestris L.) were more stable during winching tests than trees planted from $5 \mathrm{~cm}$ diameter containers, probably due to a combination of more root cross-sectional area, better root symmetry, and increased number of straight roots (Lindstrom and Rune 1999). Root spiraling was more severe and noticeable on young (7-9 year old) planted Scots pine than older (19-24 year old) planted trees.

Bending moment required to pull trunks of naturally regenerated Scots pine to 10 degrees tilt was significantly greater than for planted trees of similar size; in agreement with Nichols and Alm (1983), the difference was less pronounced for older planted trees. Both concluded and others agreed (Coutts et al. 1999) that the difference in stability between naturally regenerated and container-grown trees decreased over time as roots grow in strength to compensate for irregular root distribution. However, internal problems remaining include abnormal fiber orientation, compression wood, and inferior root strength from bark inclusions (Krasowski and Owens 2000).

Douglas-fir [seudotsuga menziesii (Milb.) Franco] from bare root and from $5 \mathrm{~cm}$ diameter containers produced similar root systems as soon as five years after planting (Sundstrom and Keane 1999). Crossed and circling roots resulting from container production on this species simply grafted together. Root deformation from containers may impact stability more on trees such as pines that are not able to form adventitious roots or graft together (Halter et al. 1993). Quercus virginiana Cathedral $\mathrm{Oak}^{\circledR}$ trees capable of producing adventitious roots can generate new straight roots above root deformations when young (Gilman et al. 2008). However, as trees grew older than about two years, Cathedral Oak lost capacity to generate adventitious roots. This suggests that some trees planted from large containers such as those used in the landscape profession could have many of their roots deflected by the container wall, even on trees capable of forming adventitious roots.

Straight horizontal roots on forest trees up to 21-yearsold result in better stability following planting (Ortega et al. 2006), than trees with root deflections. Slicing (Gilman et al. 2008) or shaving (Gilman et al. 2010a) root balls when shifting from one container size to another can increase total number of roots and number of straight roots in the root ball. Ortega et al. (2006), Lindstrom and Rune (1999), and others showed that descending roots resulting from deflection by container walls on trees planted from $5 \mathrm{~cm}$ diameter liner pots reduced stability. Little is known about impacts on tree stability from planting trees from larger containers common in the landscape trade. 
Reported effects of mechanical root pruning in containers on root growth and morphology vary. One study showed that light cutting of circling roots of shrubs enhanced amount of roots growing into container substrate outside original root ball (Blanusa et al. 2007). In contrast, Gilman et al. (1996) showed that slicing $11.3 \mathrm{~L}(22 \mathrm{~cm}$ tall $\times 25 \mathrm{~cm}$ top diameter) container root balls top-to-bottom on Burford holly (Ilex cornuta 'Burfordii') at planting into field soil resulted in a redistribution of roots, not an increase in roots compared with nonpruned controls. Krasowski and Owens (2000) found root systems of mechanically pruned Picea glauca (Moench) Voss produced greater root growth than control or chemically root pruned treatments despite a smaller root ball at planting. Burdett (1978) and Dunn at al. (1997) showed a reduction in root circling and root deflection downward in propagation container trays treated with copper hydroxide compared to untreated trays. Treated trees produced root systems post-planting similar to naturally regenerated trees resulting in enhanced stability compared to not pruning; there was identical stability between copper treated and naturally regenerated trees.

There are few studies on mechanical or chemical root pruning in large landscape-sized containers on stability following planting into landscape soil. There are no reported studies on impact of root ball composition on post-planting stability, and none have attempted to calibrate bending stress or pulling angle to wind speed. Objectives of the present study were to evaluate impact of slicing into the periphery of container root balls, initial tree size at planting, and root ball composition on post-planting tree stability in a simulated wind and rain storm.

\section{MATERIALS AND METHODS}

\section{Planting}

One-hundred-twenty Quercus virginiana Mill. 'SNDL', PP\#12015, Cathedral Oak trees propagated from cuttings were planted April 2005 into a field with Millhopper fine sand (loamy, silicacous, hyperthermic Grossarenic Paleudults) with less than $2 \%$ organic matter according to Gilman et al. (2010b). Thirty of each of the following four planting treatments were installed: $57 \mathrm{~L}$ (41 cm tall x $43 \mathrm{~cm}$ top diameter, Nursery Supplies Inc., Fairless Hills, PA, U.S.) smooth-sided containers, 170 L (47 $\mathrm{cm}$ tall $\mathrm{x} 75 \mathrm{~cm}$ top diameter) smooth-sided containers, $170 \mathrm{~L}$ smooth-sided containers sliced ( 3 to $5 \mathrm{~cm}$ deep) down the sides in six equidistant positions at planting, or transplanted from an adjacent field. Trees at planting were within standard nursery industry guidelines for root ball size (Anonymous 2004), and grew for three growing seasons after landscape planting prior to testing.

One $[(4 \mathrm{~cm} \mathrm{x} 4 \mathrm{~cm}) \times(45 \mathrm{~cm})]$ long wooden stake was driven into soil $60 \mathrm{~cm}$ east and west of trunk to monitor tree subsidence following planting. This position was just outside the periphery of the root balls. A string was stretched from top of east stake to top of west stake so it rested against tree trunk. A visible line was drawn on the trunk to mark string position at planting March 2005 and three growing seasons later October 2007.

\section{Evaluating Stability}

The Alachua County, Florida, soil survey was used to determine amount of water to add $(757 \mathrm{~L})$ and amount of time to wait (6 hours) to bring a $2.4 \mathrm{~m} \mathrm{x} 2.4 \mathrm{~m}$ plot, $1.2 \mathrm{~m}$ deep, around each tree to field capacity. The actual amount of water added was 1.5 times the amount needed $(757 \mathrm{~L}$ x $1.5=1135.5 \mathrm{~L})$, helping ensure soil saturation consistency. Water was applied in October 2007 thru PVC and four low-profile sprinkler heads, controlled by battery-operated timers. Each tree was pulled 6-6.5 hours after irrigation ceased. This allowed water to percolate into soil and drain, bringing soil to field capacity prior to evaluating tree stability. Added water simulated a large volume rain event often associated with hurricanes and other storms, and standardized soil moisture conditions among replicates.

The seven trees with a trunk diameter $15 \mathrm{~cm}$ from ground (caliper) closest to mean caliper for each planting treatment were pulled with a steel cable and electric winch (Model 40764; Chicago Electric Power Tools, Inc., Camarillo, CA, U.S.) to evaluate lateral tree stability in a strong storm. Four or five, depending on planting treatment, of the seven trees for each treatment were pulled in the 110 Azimuth (from north) direction; others were pulled in the 20 to 50 Azimuth direction. There was no prevailing wind direction at the site. An electronic inclinometer (model N4; Rieker Inc., Aston, PA, U.S.) was mounted to a fabricated steel plate (5.1 $\mathrm{cm} \times 7.6 \mathrm{~cm}$ ). The plate was secured with zip ties to trunk base $15 \mathrm{~cm}$ from soil surface which was located immediately above the swollen flare on the largest of the 28 trees pulled. A 3,629 kg capacity load cell (SSM-AF-8000; Interface Inc., Scottsdale, AZ, U.S.) was placed in-line with the steel pulling cable attached to trunk at estimated crown center of gravity. Trees were pulled so cable was parallel to ground.

The center of gravity was estimated on each tree by totaling cross-sectional area (CSA, calculated from diameter measured with a diameter tape) of all branches at the point where they emerged from the central trunk. The cable was attached to the central trunk at the centroid of the CSA, such that one-half of total branch CSA was below and above pulling point. The cable was pulled at a rate of $2 \mathrm{~cm} \cdot \mathrm{s}^{-1}$ until trunk base tilted 5 degrees relative to its nondeformed (unloaded) shape, and then cable was let slack. Trunk angle was recorded during the pull and immediately after the cable went slack; angle immediately following the pull was referred to as resting angle. One minute later, tree was pulled slowly until trunk tilted 10 degrees, let slack, and resting angle recorded. Tree was pulled to 15, 20, and 25 degrees following the same procedure. Pulling was concluded if the trunk cracked.

During pulling tests, load cell and inclinometer measurements were sampled at $2 \mathrm{~Hz}$ using a 16-bit data acquisition system (National Instruments Corporation, Austin, TX, U.S.) and displayed and archived in real-time on a laptop running LabView software (v: 7.0; National Instruments, Austin, TX, U.S.). The trunk bending stress at position of inclinometer at each 5 degree increment was calculated as: (pulling force $\times$ distance from pulling point to inclinometer $\times$ trunk radius at inclinometer $) \div\left(0.25 \pi \times\right.$ trunk radius $\left.^{4}\right)$. Trunk radius was calculated by halving diameter measured with a diameter tape.

Two randomly chosen field-grown trees and two $170 \mathrm{~L}$ container trees from blocks not pulled were subjected to a wind field generated by the machine described below to calibrate trunk tilt ( $15 \mathrm{~cm}$ from ground) resulting from pulling with tilt resulting from wind. The wind field was placed four meters from the north edge of foliage crown. Following soil saturation as described above, the wind speed was increased from ambient to $45 \mathrm{~m} \cdot \mathrm{s}^{-1}$ over 80 
seconds. Trees were blown south with a custom designed and built 2.09 MW (2800 bhp) hurricane simulator capable of replicating turbulent wind loads powered by four $522 \mathrm{~kW}$ (700 bhp) Detroit Diesel marine engines. Each engine is coupled to two tandem 135 cc closed loop hydraulic pumps (model HPV-135; Linde Hydraulics, Munich, Germany) that spin at $2300 \mathrm{rpm}$. Flow through pumps was controlled by a 10-bit digital value controller (model DVC 10-ZZZ; Linde Hydraulics) that relates a linear input signal to a pulse width modulation sent to a digital servo valve control actuating a $22 \mathrm{deg}$ swash plate. Pressure is then delivered through $120 \mathrm{MPa}$ burst pressure hoses (model FC 606-20; Aeroquip-Vickers, Inc., Cleveland, OH, U.S.) to closed loop hydraulic motors (model HMA210; Linde Hydraulics) producing approximately $201.3 \mathrm{~kW}$ (270 bhp). Direct drive hydraulic motors in turn spin a $4 \times 2$ array of $1.37 \mathrm{~m}$ diameter vane axial fans (model 54D550-VJ-1760-445T-X; Aerovent Industrial Fans, Lookout Mountain, TN, U.S.). Each fan is equipped with nine adjustable pitch blades that deliver $75 \mathrm{~m}^{3} \cdot \mathrm{s}^{-1}$ at free air delivery. Desired flow conditions are maintained through an adjustable open loop control system derived from the linear relationship between fan revolutions per minute and wind speed that accounts for inertial effects of the vane axial fans.

Six custom-designed, steel reinforced, neutral shape NACA airfoils were mounted at the trailing edge of the contraction unit directly down-wind of axial fans. Airfoils were computer controlled with a $100 \mathrm{~Hz}$ HR Textron valve (model 27B; Flow Products, Inc., Bellingham, WA, U.S.) and HR Textron dual feedback loop PID control card (model EC250GP) which instructs a 138 $\mathrm{N}-\mathrm{m}$ hydraulic rotary actuator (model HS-006-2V; Micromatic, Berne, IN, U.S.) and a custom active control system built with National Instruments Labview 8.5 software (Austin, TX, U.S.). The entire fan array rested on a trailer, making it mobile. It was hauled by tanker truck that also served as an 18,930 L radiator. The result was an actively controlled hurricane simulation capable of creating $\sim 1 \mathrm{kPa}$ velocity pressure. The control system modulated wind speed by varying fan RPM. The control system utilized multiple fast running PID-control assembled with National Instruments hardware (NI PXIe-6704 chassis and NI PXI-6704 analog output data acquisition card) and a custom active control system operated in the Labview environment.

\section{Root Measurements}

Trees were dug from soil using a $137 \mathrm{~cm}$ diameter tree spade following pulling; soil was washed from outer edge of root ball. The diameter of all roots $>3 \mathrm{~mm}$ diameter was measured $5 \mathrm{~cm}$ beyond the original (at planting) root ball edge in top $25 \mathrm{~cm}$ of soil profile. Only roots in top $25 \mathrm{~cm}$ soil were excavated since Marshall and Gilman (1998) found few differences between nursery production methods at greater depths. Root diameter on each root was measured by averaging largest diameter and diameter perpendicular to largest. Distance between root and soil surface was recorded as root depth. Azimuth north from trunk center to point of root diameter measurement was recorded for each root; roots were divided into those growing out into soil from $0-13 \mathrm{~cm}$ and $13-25 \mathrm{~cm}$ depths. Azimuth was then divided into six equal parts including leeward (toward winch) and windward (away from winch) one-sixth (60 degree) sections, and leeward and windward one-half (180 degree) sections.

\section{Statistical Analysis}

Trunk bending moment (pulling force $\times$ distance from pulling point to inclinometer), trunk bending stress, trunk angle from unloaded start position (tilt) in pulling tests, root diameter, root number, root CSA, resting angle, and tree subsidence were compared among four planting treatments using GLM one-way analysis of variance in SAS. Means were compared using Duncan's multiple range test. Tilt values measured during wind tests were compared between field and $170 \mathrm{~L}$ container treatments with t-test. The presence of trunk cracks was compared using proc GENMOD command in SAS as a binomial and $\log _{10}$ transformed; planting treatments were compared using the Contrast statement. Trunk caliper and overturning moment were $\log _{10}$ transformed and regressed onto one another to calculate exponent $\mathrm{b}$ in the equation: moment $=\mathrm{a}$ (caliper $)^{\mathrm{b}}$, $\mathrm{a}$ $=$ moment when caliper $=1$. The GLM procedure was used to calculate least squares coefficients of linear and quadratic relationships between bending moment and trunk caliper + root CSA .

\section{RESULTS}

Trees transplanted from the field produced more root CSA into landscape soil and root CSA $\left(\mathrm{cm}^{2}\right) / \mathrm{cm}^{2}$ trunk CSA, greater root diameter, and greater mean diameter of the 10 largest roots than trees from either $57 \mathrm{~L}$ or $170 \mathrm{~L}$ containers (Table 1). There was no difference in root CSA for trees planted from $57 \mathrm{~L}$ compared to $170 \mathrm{~L}$ containers. Trees transplanted from the field also had greater number of roots growing into landscape soil than trees planted from either container size (Table 1; Figure 1; Figure 2). Root number $/ \mathrm{cm}^{2}$ trunk CSA for field trees was greater than for trees planted from $170 \mathrm{~L}$ containers, but was similar to trees planted from $57 \mathrm{~L}$ containers. Root diameter/ $\mathrm{cm}^{2}$ trunk CSA was greater for trees planted from $57 \mathrm{~L}$ containers than trees planted from any other treatment except field-grown trees.

Trees planted from $57 \mathrm{~L}$ containers settled deeper into landscape soil the first three growing seasons following planting than trees from $170 \mathrm{~L}$ containers and trees transplanted from field (Table 1). Trees planted from $170 \mathrm{~L}$ containers also settled deeper than field-grown trees. In contrast to container-grown trees, field-grown trees rose two millimeters out of the ground the first three growing seasons after transplanting.

Trees planted three growing seasons previously from $170 \mathrm{~L}$ containers tilted significantly more $(P<0.01)$ than trees transplanted from the field when subjected to a given wind speed up to $45 \mathrm{~m} \cdot \mathrm{s}^{-1}$ (Table 2). Tilting the lower trunk on field transplanted trees to about three degrees and $170 \mathrm{~L}$ container planted trees to about 10 degrees corresponded to approximately $45 \mathrm{~m} \cdot \mathrm{s}^{-1}$ wind.

Bending moment required to tilt the lower trunk $10 \mathrm{de}$ grees from the nonloaded start position was less for trees planted from $57 \mathrm{~L}$ containers than other treatments; the bending moment required to tilt trunk 10 degrees was greater for trees transplanted from the field (Table 3). A least squares regression for all 28 trees in the study of bending moment $\left(\mathrm{M}_{B}\right.$ in $\left.\mathrm{kNm}\right)$ against trunk caliper $(\mathrm{cm})$ showed a significant relationship existed according to Equation 1.

[Equation 1] $\quad \mathrm{M}_{\mathrm{B}}$ around base $(\mathrm{kNm})$ to 10 degrees trunk tilt $=1.77$ trunk caliper $(\mathrm{cm})-14.07, \mathrm{R}^{2}=0.86$, intercept and slope $P<0.001$. 
Table 1. Root cross-sectional area (CSA), root number, root diameter, and tree subsidence on Cathedral Oak live oak, three growing seasons following planting.

\begin{tabular}{|c|c|c|c|c|c|c|c|c|c|}
\hline Planting treatment ${ }^{2}$ & $\begin{array}{l}\text { Trunk caliper } \\
\text { when pulled } \\
(\mathrm{cm})\end{array}$ & $\begin{array}{l}\text { Total root } \\
\text { CSA }^{y}\left(\mathrm{~cm}^{2}\right)\end{array}$ & $\begin{array}{l}\text { Root CSA }\left(\mathrm{cm}^{2}\right) \\
/ \mathrm{cm}^{2} \text { trunk } \mathrm{CSA}^{\mathrm{x}}\end{array}$ & $\begin{array}{c}\text { Total root } \\
\text { no. }{ }^{\text {w }}\end{array}$ & $\begin{array}{c}\text { Root no. } / \mathrm{cm}^{2} \\
\text { trunk CSA }\end{array}$ & $\begin{array}{c}\text { Root } \\
\text { diameter } \\
(\mathrm{mm})\end{array}$ & $\begin{array}{l}\text { Root diam. }(\mathrm{mm}) \\
/ \mathrm{cm}^{2} \text { trunk CSA }\end{array}$ & $\begin{array}{l}\text { Diameter }(\mathrm{mm}) \\
\text { of } 10 \text { largest } \\
\text { roots }\end{array}$ & $\begin{array}{l}\text { Tree } \\
\text { subsidence }^{u} \\
(\mathrm{~mm})\end{array}$ \\
\hline 57 L container & $85 c$ & $20.1 b^{t}$ & $0.34 b^{t}$ & $36 \mathrm{c}^{\mathrm{t}}$ & $0.62 a b^{t}$ & $7.3 b^{t}$ & $0.13 \mathrm{a}^{\mathrm{t}}$ & $12.8 b^{t}$ & $-5(-22$ to +3$) c$ \\
\hline $170 \mathrm{~L}$ container/ not sliced & $113 b$ & $27.7 b$ & $0.27 \mathrm{~b}$ & $55 \mathrm{~b}$ & $0.54 \mathrm{~b}$ & $6.7 \mathrm{~b}$ & $0.07 \mathrm{~b}$ & $14.1 \mathrm{~b}$ & $-2(-13$ to +5$) b$ \\
\hline 170 L container/ sliced & $115 b$ & $25.9 \mathrm{~b}$ & $0.24 b$ & $55 \mathrm{~b}$ & $0.52 b$ & $6.7 \mathrm{~b}$ & $0.06 \mathrm{~b}$ & $13.5 b$ & $-3(-13$ to +3$) b$ \\
\hline Field grown & $132 \mathrm{a}$ & $105.6 \mathrm{a}$ & $0.69 \mathrm{a}$ & $115 \mathrm{a}$ & $0.76 \mathrm{a}$ & $8.3 \mathrm{a}$ & $0.06 \mathrm{~b}$ & $25.4 \mathrm{a}$ & $+2(-5$ to +16$) \mathrm{a}$ \\
\hline
\end{tabular}

${ }^{\mathrm{z}} 57 \mathrm{~L}$ container $=29 \mathrm{~mm}$ caliper trees from $57 \mathrm{~L}$ container; $170 \mathrm{~L}$ container/not sliced $=67 \mathrm{~mm}$ caliper trees from $170 \mathrm{~L}$ container with no root ball slicing at planting;

$170 \mathrm{~L}$ container/sliced $=67 \mathrm{~mm}$ caliper trees from $170 \mathrm{~L}$ container with root ball sliced top to bottom in 6 places at planting; field grown $=80 \mathrm{~mm}$ caliper trees dug from field soil, all planted March 2005.

y Total CSA of roots $>3 \mathrm{~mm}$ diameter growing into landscape soil from the top $25 \mathrm{~cm}$ of root ball measured $5 \mathrm{~cm}$ beyond edge of root ball.

x Trunk CSA measured $15 \mathrm{~cm}$ from ground.

${ }^{w}$ Total number of roots $>3 \mathrm{~mm}$ diameter $5 \mathrm{~cm}$ beyond the edge of root ball.

${ }^{v}$ Mean diameter for roots $>3 \mathrm{~mm}$ diameter growing into landscape soil from the top $25 \mathrm{~cm}$ of root ball measured $5 \mathrm{~cm}$ beyond edge of root ball.

"Mean (and range) subsidence (-= tree sunk lower into ground; += tree lifted out of ground) three growing seasons after planting on 30 trees per treatment; means in a column followed by a different letter are statistically different at $P<0.05$.

${ }^{\mathrm{t}}$ Mean of seven trees per treatment; means in a column followed by a different letter are statistically different at $P<0.05$.

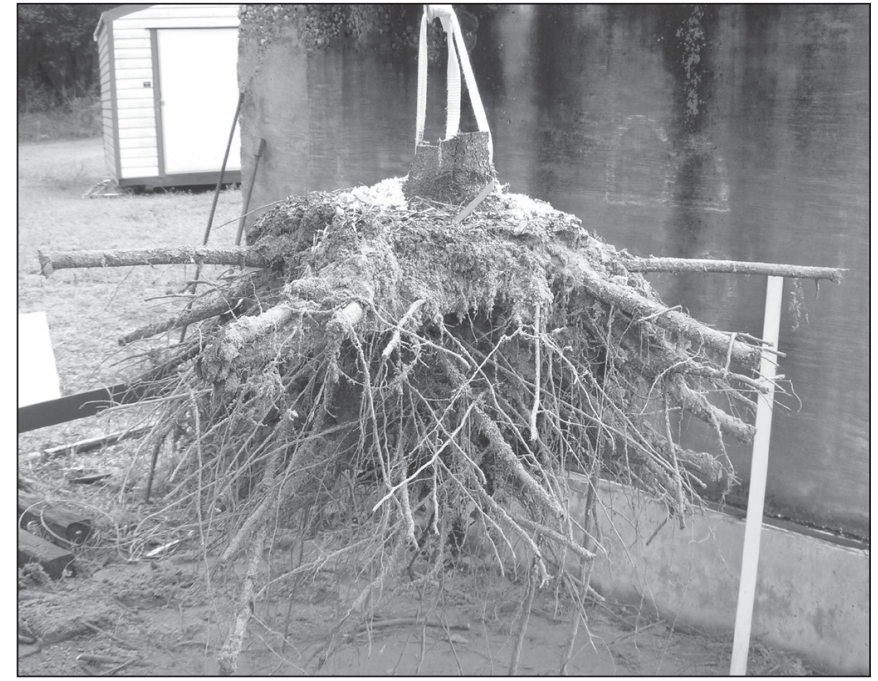

Figure 1. Root system of field-grown tree, three growing seasons after transplanting to landscape. An average of 115 roots $>3 \mathrm{~mm}$ diameter grew into the top $25 \mathrm{~cm}$ of landscape soil. Note roots growing radially from edge of original root ball.

Therefore, bending moment was correlated with trunk diameter as others have shown on forest trees (Stokes 1999). In order to determine how $M_{B}$ scaled with caliper, $\log _{10} M_{B}$ was regressed against $\log _{10}$ trunk caliper for each planting treatment (Figure 3) and then for all 28 trees combined, which resulted in the following relationship:

[Equation 2] $\quad \log _{10} \mathrm{M}_{\mathrm{B}}$ around base $(\mathrm{kNm})$ to 10 degrees trunk tilt $=3.40 \log _{10}$ trunk caliper $(\mathrm{cm})-2.86 ; \mathrm{R}^{2}=0.93$, intercept and slope $P<0.001$.

Trunks on five of seven field-grown trees cracked as they were pulled, which was more than other treatments (Table $3)$. There was no statistical difference in number of trunks cracked when pulled between trees planted from the two container sizes. Trees transplanted from the field required more bending stress to tilt trunk 5 or 10 degrees than any other planting treatment (Figure 4). However, there was no difference between trees planted from $57 \mathrm{~L}$ containers and

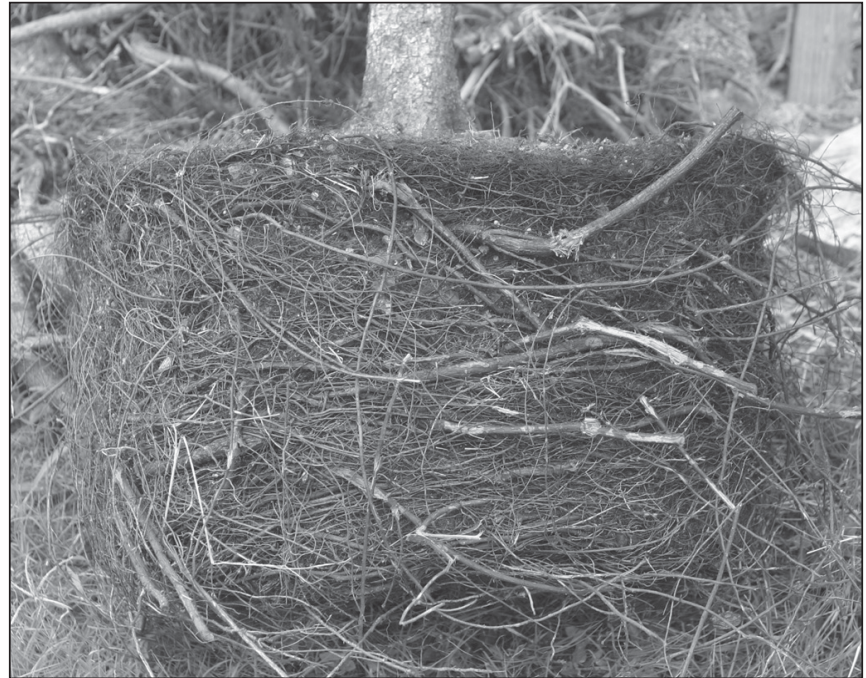

Figure 2. Root system of tree from $170 \mathrm{~L}$ container, either sliced or not when planted, three growing seasons after planting into landscape. An average of 55 roots grew into the top $25 \mathrm{~cm}$ of landscape soil. Note roots growing along root ball periphery tangent to trunk before entering landscape soil.

Table 2. Calibration of trunk tilt in degrees from unloaded starting position $15 \mathrm{~cm}$ from ground with wind speed for Cathedral Oak planted from $170 \mathrm{~L}$ containers and transplanted from the field.

\begin{tabular}{lcc}
\hline $\begin{array}{l}\text { Wind speed } \\
\mathrm{m} \cdot \mathrm{s}^{-1}(\mathrm{mph})\end{array}$ & $\begin{array}{c}\text { Trunk tilt (degrees) } \\
\text { 170 L containers }\end{array}$ & Field grown \\
\hline $18(40)$ & $4.1 \mathrm{az}$ & $0.8 \mathrm{~b}$ \\
$27(60)$ & $8.9 \mathrm{a}$ & $2.3 \mathrm{~b}$ \\
$36(80)$ & $9.2 \mathrm{a}$ & $2.3 \mathrm{~b}$ \\
$45(100)$ & $10.3 \mathrm{a}$ & $2.8 \mathrm{~b}$ \\
\hline
\end{tabular}

${ }^{\mathrm{z}}$ Means from two replicates in a row with different letters are statistically different with t-test at $P<0.01$.

trees transplanted from the field in bending stress required to pull trunks 15 degrees (Figure 4) or more (data not shown). Slicing $170 \mathrm{~L}$ container root balls at planting had no impact on bending stress (Figure 4) or bending moment (Table 3) required to pull trees to any angle. Trunk tilt immediately fol- 


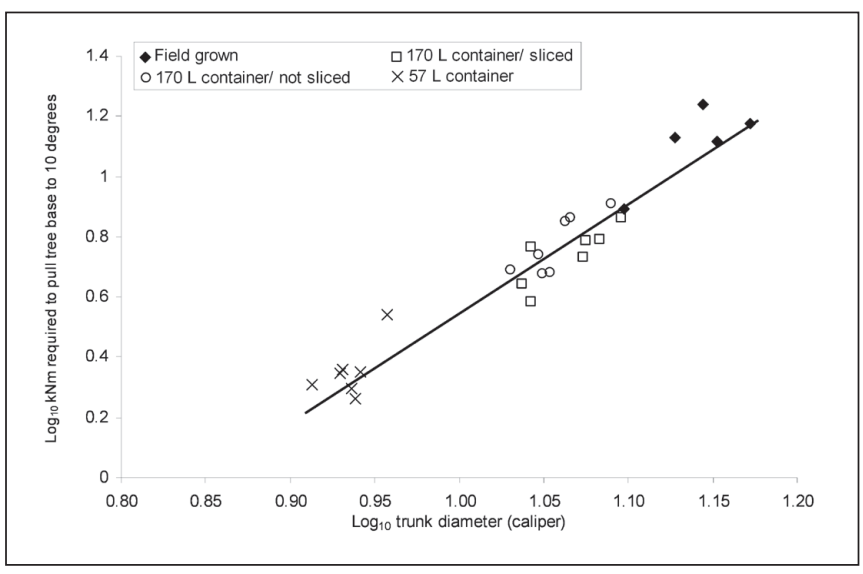

Figure 3. $\log _{10}$ overturning bending moment (kNm) required to tilt trunk base 10 degrees to $\log _{10}$ trunk diameter $15 \mathrm{~cm}$ from ground for four planting treatments. $\log _{10} M_{B}(\mathrm{kNm})$ $=3.40 \log _{10}$ trunk diameter $(\mathrm{cm})-2.86 ; \mathbf{R}^{2}=0.93$; intercept and slope $P<0.001$.

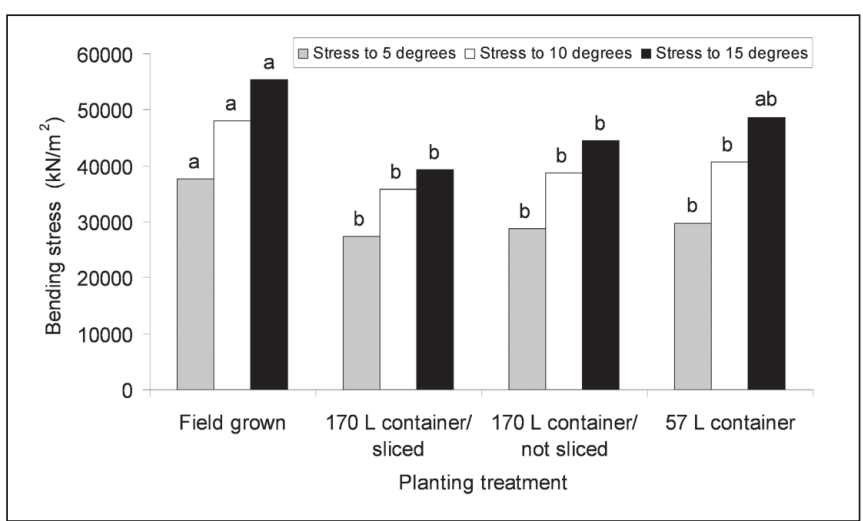

Figure 4. Calculated trunk bending stress $(\mathrm{kN} / \mathrm{m} 2) 15 \mathrm{~cm}$ from ground resulting from pulling trees to various angles for four planting treatments. Bending stress $=$ (pulling force $\times$ distance from pulling point to inclinometer $x$ trunk radius at inclinometer) $\div\left(0.25 \pi \times\right.$ trunk radius $\left.{ }^{4}\right)$. Planting treatments with a different letter are statistically different $(P<0.05)$, for a given angle in degrees.

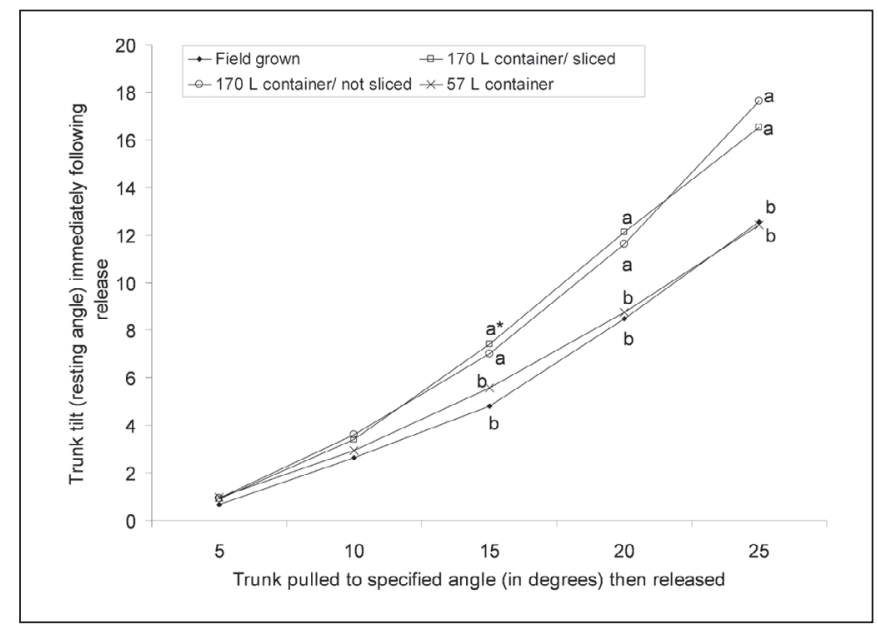

Figure 5. Trunk tilt (resting angle) $15 \mathrm{~cm}$ from ground immediately following pulling trees to various angles then releasing for four planting treatments (asterisks indicate means for a given angle with different letters are statistically different at $P<0.05$ ) lowing release (resting angle) was similar among all planting treatments after pulls to 5 and 10 degrees (Figure 5). Trees planted from $170 \mathrm{~L}$ containers remained more tilted than trees planted from either $57 \mathrm{~L}$ containers or from the field following pulls to 15,20 , and 25 degrees trunk tilt.

Many root attributes correlated with trunk bending stress during pulling tests to 10 degree tilt from vertical starting position (Table 4). Highest Pearson's correlation coefficients were related to total root CSA or root CSA on windward side of trees. Root diameter attributes, including total root diameter and largest diameter root windward, appeared next best correlated, followed by number of roots. Root diameter appeared best correlated with maximum bending stress when trunks were pulled to 25 degrees.

Pearson's correlation coefficient between root CSA and bending moment was significant only for trees transplanted from the field, not for trees planted from containers of either size (Table 5). Bending stress was not significant correlated with root CSA for any planting treatment. However, Pearson's correlation coefficient between root CSA and both bending moment and bending stress was significant when all 28 trees across planting treatments were analyzed together. In general, correlations were higher for bending moment than for bending stress. Trunk bending moment was highly predictable from a combination of trunk diameter (caliper) and root CSA according to Equation 3.

[Equation 3] $\quad \mathrm{M}_{\mathrm{B}}$ around trunk base $(\mathrm{kNm})$ to 10 degrees trunk tilt $=0.097$ trunk caliper $(\mathrm{cm})+0.00052$ root CSA $\left(\mathrm{cm}^{2}\right)$ $-7.21 ; \mathrm{R}^{2}=0.97$, intercept and slope $P<0.001$, all 28 trees combines.

Trunk bending stress $/ \mathrm{cm}^{2}$ root CSA was significantly less for trees transplanted from field than planted from containers of either size for all trunk tilt angles (Table 6). Bending stress $/ \mathrm{cm}^{2}$ root CSA was less for trees planted from $170 \mathrm{~L}$ containers sliced or not than trees from $57 \mathrm{~L}$ containers during pulls to 10 and 15 degree tilt from vertical start position.

Table 3. Number of trunks that visibly cracked and trunk bending moment during pulling tests of four planting treatments, three growing seasons after landscape installation.

\begin{tabular}{lcc}
\hline Planting treatment & $\begin{array}{c}\text { No. of trunks cracked } \\
\text { during pulling test }\end{array}$ & $\begin{array}{c}\text { Bending moment to } \\
10 \text { degrees trunk tilt } \\
(\mathrm{kNm})\end{array}$ \\
\hline 57 L container & $2^{\mathrm{y}} \mathrm{b}^{\mathrm{x}}$ & $2.3 \mathrm{c}$ \\
170 L container/ not sliced & $0 \mathrm{~b}$ & $5.5 \mathrm{~b}$ \\
170 L container/ sliced & $0 \mathrm{~b}$ & $5.6 \mathrm{~b}$ \\
Field grown & $5^{\mathrm{w}} \mathrm{a}$ & $12.4 \mathrm{a}$ \\
\hline
\end{tabular}

z $57 \mathrm{~L}$ container $=29 \mathrm{~mm}$ caliper trees from $57 \mathrm{~L}$ container; $170 \mathrm{~L}$ container/not sliced $=67 \mathrm{~mm}$ caliper trees from $170 \mathrm{~L}$ container with no root ball slicing at planting; $170 \mathrm{~L}$ container/sliced $=67 \mathrm{~mm}$ caliper trees from $170 \mathrm{~L}$ container with root ball sliced top to bottom in six places at planting; field grown $=80 \mathrm{~mm}$ caliper trees dug from field soil, all planted March 2005

${ }^{y}$ Trunks cracked as trees were pulled to 15 or 20 degrees.

x Seven trees per treatment; means in a column followed by a different letter are statistically different at $P<0.05$.

${ }^{w}$ Three trunks cracked while attempting to pull trunk base to 15 degrees; two cracked while attempting to pull to 20 degrees. 
Table 4. Root ( $>3 \mathrm{~mm}$ diameter) attributes correlated with trunk bending stress ${ }^{2}$ during tree pulling tests on 28 trees from four planting treatments combined.

\begin{tabular}{|c|c|c|}
\hline & \multicolumn{2}{|c|}{ Trunk bending stress when trunk pulled to } \\
\hline & $\begin{array}{l}10 \text { degrees } \\
\text { from } \\
\text { vertical }\end{array}$ & $\begin{array}{l}\text { Maximum }{ }^{y} \\
\text { trunk bending } \\
\text { stress }\end{array}$ \\
\hline Root attributes & \multicolumn{2}{|c|}{ Pearson's correlation coefficient ${ }^{\mathrm{x}}$} \\
\hline Root CSA (windward 1/2) ${ }^{\mathrm{w}}$ & 0.68 & 0.31 \\
\hline Total root CSA & 0.64 & 0.31 \\
\hline Root CSA (0-13 cm soil depth) & 0.61 & 0.31 \\
\hline Root CSA (14-25 cm soil depth) & 0.59 & NS \\
\hline Diameter of largest root (windward 1/6) ${ }^{\mathrm{v}}$ & 0.59 & 0.32 \\
\hline Root CSA (windward $1 / 6)^{\mathrm{v}}$ & 0.58 & 0.31 \\
\hline Root CSA (windward 1/2, 14-25 cm soil depth) ${ }^{w}$ & 0.58 & NS \\
\hline Total root diameter & 0.57 & 0.48 \\
\hline Diameter of largest root (windward $1 / 6,0-13 \mathrm{~cm}$ soil depth) ${ }^{v}$ & 0.57 & 0.43 \\
\hline Mean root diameter (windward $1 / 2)^{\mathrm{w}}$ & NS & 0.53 \\
\hline Number of roots (windward $1 / 2)^{\mathrm{w}}$ & 0.51 & NS \\
\hline Total root CSA area (leeward 1/6, 14-25 cm soil depth) ${ }^{\mathrm{u}}$ & NS & 0.45 \\
\hline Total number of roots & 0.45 & NS \\
\hline Number of roots (windward $1 / 6)^{v}$ & 0.45 & NS \\
\hline Root number (windward 1/2)w & 0.45 & NS \\
\hline Root CSA (windward 1/6) ${ }^{\mathrm{v}}$ & 0.45 & 0.31 \\
\hline Number of roots (14-25 cm soil depth) & 0.44 & NS \\
\hline Number of roots (0-13 cm soil depth) & 0.39 & NS \\
\hline Number of roots (leeward $1 / 2)^{t}$ & 0.36 & NS \\
\hline Root diameter (windward $1 / 6)^{v}$ & 0.33 & 0.53 \\
\hline
\end{tabular}

${ }^{\mathrm{z}}$ Trunk bending stress $=($ pulling force $\times$ length $\times$ trunk radius $) \div\left(0.25 \pi \times\right.$ trunk $\left.^{\text {radius }}{ }^{4}\right)$.

${ }^{y}$ Maximum trunk bending stress encountered as trees were pulled to 25 degrees trunk tilt in five degree increments.

x Significantly correlated at $P<0.01 ;$ NS indicates not significant at $P<0.01$.

${ }^{w}$ Roots in the 180 degree section opposite pulling winch.

${ }^{v}$ Roots in the 60 degree section opposite pulling winch.

"Roots in the 60 degree section toward pulling winch.

${ }^{\mathrm{t}}$ Roots in the 180 degree section toward pulling winch.

Table 5. Pearson's correlation coefficient between trunk bending moment or trunk bending stress and root cross sectional area (CSA) for four planting treatments three growing seasons after planting.

\begin{tabular}{|c|c|c|c|c|c|c|}
\hline \multirow[b]{3}{*}{ Planting treatment ${ }^{\mathrm{y}}$} & \multicolumn{6}{|c|}{ Degrees of trunk tilt $15 \mathrm{~cm}$ from ground } \\
\hline & \multicolumn{2}{|c|}{5 degrees } & \multicolumn{2}{|c|}{10 degrees } & \multicolumn{2}{|c|}{15 degrees } \\
\hline & Moment $^{x}$ & Stress $^{w}$ & Moment & Stress & Moment & Stress \\
\hline \multicolumn{7}{|c|}{ Pearson's correlation coefficient } \\
\hline $57 \mathrm{~L}$ container $^{\mathrm{v}}$ & 0.58 & 0.12 & 0.67 & 0.34 & 0.66 & 0.42 \\
\hline $57 \mathrm{~L}$ container/ not sliced ${ }^{\mathrm{v}}$ & 0.30 & -0.49 & 0.39 & -0.26 & 0.45 & -0.03 \\
\hline $170 \mathrm{~L}$ container/ sliced ${ }^{\mathrm{v}}$ & -0.07 & -0.40 & 0.00 & -0.32 & 0.13 & -0.16 \\
\hline Field-grown ${ }^{v}$ & $0.85^{*}$ & 0.51 & $0.93 * *$ & 0.67 & $0.93 *$ & 0.64 \\
\hline All planting treatments ${ }^{u}$ & $0.93 * *$ & $0.68 * *$ & $0.93 * *$ & $0.64 * *$ & $0.93 * *$ & $0.53 * *$ \\
\hline
\end{tabular}

${ }^{\mathrm{z}} \mathrm{CSA}$ of roots $>3 \mathrm{~mm}$ diameter growing into landscape soil from the top $25 \mathrm{~cm}$ of root ball measured $5 \mathrm{~cm}$ beyond edge of original root ball.

y $57 \mathrm{~L}$ container $=29 \mathrm{~mm}$ caliper trees from $57 \mathrm{~L}$ container; $170 \mathrm{~L}$ container/not sliced $=67 \mathrm{~mm}$ caliper trees from $170 \mathrm{~L}$ container with no root ball slicing at planting; $170 \mathrm{~L}$ container/sliced $=67 \mathrm{~mm}$ caliper trees from $170 \mathrm{~L}$ container with root ball sliced top to bottom in six places at planting; field grown $=80 \mathrm{~mm}$ caliper trees dug from field soil, all planted March 2005

${ }^{\mathrm{x}}$ Moment (trunk bending moment) $=$ pulling force $\mathrm{x}$ distance from pulling point to point of inclinometer $15 \mathrm{~cm}$ from ground.

${ }^{\mathrm{w}}$ Stress (trunk bending stress) $=($ pulling force $\times$ distance from pulling point to inclinometer $\times$ trunk radius $) \div\left(0.25 \pi \times\right.$ trunk radius $\left.{ }^{4}\right)$.

${ }^{v}$ Based on seven trees per planting treatment.

"Based on all 28 trees across planting treatment.

**Significantly different from zero at $P<0.01 ; *$ Significantly different from zero at $P<0.05$. 
Table 6. Trunk bending stress ${ }^{z}$ per $\mathrm{cm}^{2}$ root $\mathrm{CSA}^{y}\left(\mathrm{MPa} / \mathrm{cm}^{2}\right)$ required to tilt lower trunk to three angles for four planting treatments three growing seasons after planting.

\begin{tabular}{llcc}
\hline & \multicolumn{3}{c}{ Trunk tilt angle (vertical degrees from } \\
start position) \\
Planting treatment ${ }^{\mathrm{x}}$ & 5 degrees & 10 degrees & 15 degrees \\
\hline 57 L container & $16.0 \mathrm{a}^{\mathrm{w}}$ & $21.7 \mathrm{a}$ & $25.9 \mathrm{a}$ \\
170 L container/ not sliced & $12.0 \mathrm{a}$ & $15.7 \mathrm{~b}$ & $17.1 \mathrm{~b}$ \\
170 L container/ sliced & $11.5 \mathrm{a}$ & $15.3 \mathrm{~b}$ & $17.6 \mathrm{~b}$ \\
Field grown & $3.8 \mathrm{~b}$ & $4.9 \mathrm{c}$ & $5.5 \mathrm{c}$ \\
\hline
\end{tabular}

${ }^{\mathrm{z}}$ Bending stress $=($ pulling force $\times$ distance from pulling point to inclinometer $\times$ trunk radius $) \div\left(0.25 \pi \times\right.$ trunk radius $\left.{ }^{4}\right)$.

${ }^{y} \mathrm{CSA}\left(\mathrm{cm}^{2}\right)$ of roots $>3 \mathrm{~mm}$ diameter growing into landscape soil from the top $25 \mathrm{~cm}$ of root ball measured $5 \mathrm{~cm}$ beyond edge of original root ball.

$\times 57 \mathrm{~L}$ container $=29 \mathrm{~mm}$ caliper trees from $57 \mathrm{~L}$ container; $170 \mathrm{~L}$ container $/ \mathrm{not}$ sliced $=67 \mathrm{~mm}$ caliper trees from $170 \mathrm{~L}$ container with no root ball slicing at planting; $170 \mathrm{~L}$ container/sliced $=67 \mathrm{~mm}$ caliper trees from $170 \mathrm{~L}$ container with root ball sliced top to bottom in 6 places at planting; field grown $=80 \mathrm{~mm}$ caliper trees dug from field soil, all planted March 2005.

w Seven trees per treatment; means in a column followed by a different letter are statistically different at $P<0.001$.

\section{DISCUSSION}

Slicing the outside periphery of $170 \mathrm{~L}$ container root balls in six places from top of root ball to bottom had no impact on tree stability three growing seasons after landscape planting, whether measuring bending moment (Table 3 ) or bending stress required to pull trees to increasing trunk tilts (Figure 4), or trunk resting angle immediately following release from a pull test (Table 5). This was not surprising since there was no impact on root growth into landscape soil from root ball slicing (Table 1). There is little published on container-grown trees of this size responding to mechanical root pruning (Gilman et al. 2010b) and no reports of stability measurements; however, others have shown on much smaller containers a redistribution (Gilman et al. 1996) or increase (Blanusa et al. 2007) in root number from mechanical slicing root balls at planting. Perhaps shaving off or removing the entire outer periphery of root ball at planting will increase root number and soil volume explored by roots as occurred when shifting trees from 11.3 L containers into 57 L containers (Gilman et al. 2010a).

Field-grown trees were more stable than comparably sized trees planted from $170 \mathrm{~L}$ containers requiring significantly more bending stress to reach 5, 10, 15 (Figure 4) or more (data not shown) degrees trunk tilt. Bending stress normalized bending moment to account for or remove the affect of a $13 \%$ difference in trunk caliper between these treatments when pulled (Table 1). In addition, trunk resting angle was less for trees transplanted from the field immediately following release from 15, 20, and 25 degree pulling tests than trees planted from $170 \mathrm{~L}$ containers (Figure 5). Reduced trunk resting angle $15 \mathrm{~cm}$ from ground indicated less permanent root ball overturning and hence stronger attachment to landscape soil. Using the calibration in Table 2, it is clear that trees transplanted from the field would have required much greater wind speed than $45 \mathrm{~m} \cdot \mathrm{s}^{-1}$ to tilt lower trunk five degrees; whereas, trees planted from containers in $45 \mathrm{~m} \cdot \mathrm{s}^{-1}$ wind tilted more than 10 degrees. Others also found that bending moment required to pull trunks to a 10 degree tilt was influenced by nursery production method for small seedlings planted as part of reforestation (Lindstrum and Rune 1999). Root systems on trees transplanted from the field were so stable that five of seven tree trunks broke as they were pulled past 15 degrees; whereas, no trees planted from $170 \mathrm{~L}$ containers broke because root balls overturned. The study authors could not estimate the wind speed required to tilt field-grown tree trunks to $15 \mathrm{de}-$ grees because this was well beyond our calibration; however, Table 2 shows that $45 \mathrm{~m} \cdot \mathrm{s}^{-1}$ wind tilted trunks just three degrees.

Several factors could explain reduced stability of trees planted from $170 \mathrm{~L}$ containers compared to transplanted field-grown trees. Trees from $170 \mathrm{~L}$ containers had one-quarter the root CSA into landscape soil, one-third the root $\mathrm{CSA} / \mathrm{cm}^{2}$ of trunk CSA, one-half the number of roots, two-thirds the number of roots $/ \mathrm{cm}^{2}$ trunk CSA, and smaller diameter roots measured just outside the original root ball compared to field-grown trees (Table 1). The slightly (13\%) smaller (Table 1) trunk diameter on $170 \mathrm{~L}$ container trees when pulled does not account for the dramatically less (one-fourth) root CSA area outside original root ball which Mickovski and Ennos (2002) showed scaled to the 1.7 power of trunk diameter. Root deflection downward or around container walls can also reduce stability (Lindstrom and Rune 1999, Ortega et al. 2006); in the present study, roots appeared to be deflected by each of three container sizes (3.7 L, $57 \mathrm{~L}$, and $170 \mathrm{~L}$ ). Despite trees of this size becoming established by about 18 months after planting in hardiness zone 8 (Gilman et al. 2010b) a substantial portion of large roots on $170 \mathrm{~L}$ container trees likely remained in the original root ball substrate volume three years after planting. For example, Gilman and Kane (1991) found that about 50\% of root length was still inside original $11.3 \mathrm{~L}$ container root ball three years after planting Juniperus chinensis L. shrubs of four cultivars. In addition, trees in containers have greater root density inside the root ball due to deflected roots compared to trees grown in a field nursery (Harris and Gilman 1993; Figure 6; Figure 7).

In contrast, roots were fairly straight to root ball edge on fieldgrown trees in the current study (Figure 7) because $<25 \mathrm{~mm}$ trunk caliper Cathedral Oak generate new roots from the root flare (Gilman and Harchick 2008); when 3.7 L liners of Cathedral Oak were planted into the field nursery in the current study they were approximately $13 \mathrm{~mm}$ caliper indicating retained capacity to generate new roots from the root flare. Larger diameter (Table 1) straight roots (Figure 7) on trees from the field likely contributed to (Mickovski and Ennos 2002) increased bending stress required to pull trees (Figure 4), and reduced resting angle following pulling (Figure 5). Roots on trees transplanted from the field were immediately placed in tension, as Stokes (1999) showed when trees were subjected to lateral load from winching. The main roots in the current study did not form large branch roots and tapered little to the edge of the root ball (Figure 1; Figure 7); branching or significant bending results in a hinge point or fulcrum on the lee side when loaded laterally (Coutts et al. 1999). Trunk bending stress on trees pulled from $170 \mathrm{~L}$ containers was transferred into a more complex array of deflected roots (Figure 6 ), and then into fewer and smaller (compared to trees transplanted from field; Table 1) diameter roots just outside the original root ball. In addition, some roots grew along the periphery of 170 $\mathrm{L}$ root ball tangent to trunk for some distance prior to growing into landscape soil (Figure 2). Young roots tangent to trunk likely provide less stability than radially oriented straight roots when loaded in tension (Coutts 1983; Harrington and Howell 1998). In addition, secondary roots originating from main roots growing along container walls also deflect and grow along the wall. Main roots may produce only one set of secondary roots unless injured later. The suberization of these main roots (South and Mitchell 
2005) may explain why trees from $170 \mathrm{~L}$ containers produced only one-quarter the root CSA into landscape soil as trees from the field nursery. Perhaps trees retained in a container for a shorter period could produce more roots quickly into landscape soil.

The natural condition of tree roots appears to be fairly straight for the first half meter or more from the trunk (Stout 1956; Lyford and Wilson 1964; Gilman et al. 1987). There was good correlation ( $\mathrm{r}=0.85$ to 0.93 , depending on trunk tilt) between trunk bending moment and root CSA for field-transplanted trees (Table 5). Lack of straight roots could explain why there was poor correlation between moment or stress and root CSA on trees planted from $57 \mathrm{~L}$ and $170 \mathrm{~L}$ container trees. As stress was transferred from the trunk base into roots on field-grown trees, they resisted stress and held the trunk in place with little overturning because there were many roots on the lee side pushing against mineral soil in the root ball and in the landscape (Figure 4). Roots on container trees were bent around and/or down (Figure 2; Figure 6), as others have shown on large containers (Gilman et al. 2010c), which has been associated on smaller containers with reduced stability (Ortega et al. 2006). Field trees produced four times the root CSA as trees from $170 \mathrm{~L}$ containers just outside original root ball edge. The likely result was more root mass closer to, and directly under, the trunk on container-grown trees (although mass was not measured) because roots were deflected down and around instead of growing radially out as in trees from the field.

Soil and root mass on the windward side of trees contributes to overturning resistance (Fourcaud et al. 2007). Coutts (1986) found $13 \%$ to $45 \%$ of anchorage was attributed to soil and root mass in the root-soil plate. In organic substrate there was less resistance to overturning due to lower soil density (Fraser and Gardiner 1967). Less substrate mass in a container root ball than in a field root ball of mineral soil would reduce overturning resistance. In some sense, the stiff complex of enlarging deflected roots rotated inside low density organic container substrate as the trunk was pulled or blown laterally. Therefore, it may be reasonable to encourage rapid growth in roots pointed away from the container substrate perhaps by discouraging development (Gilman et al. 2010a) of this deflected root complex so

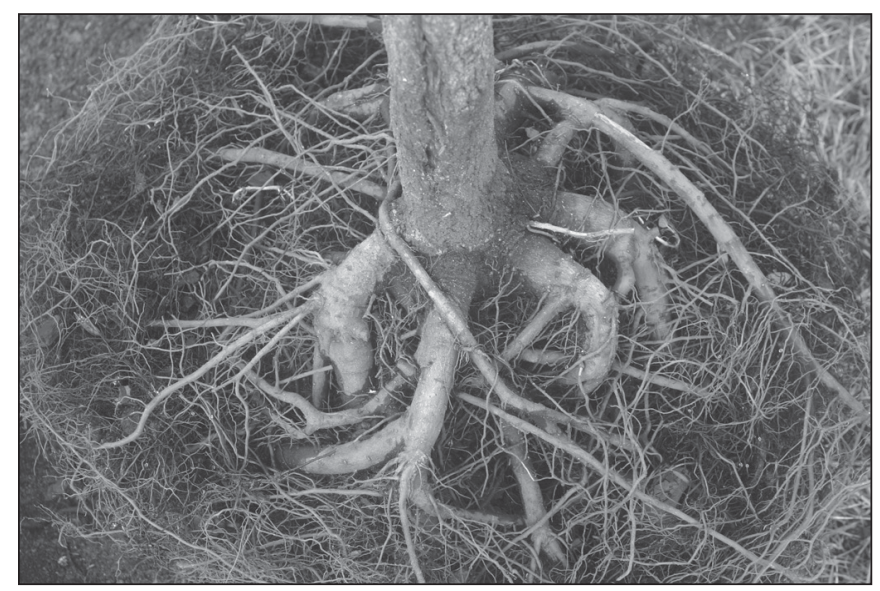

Figure 6. Root system configuration of $170 \mathrm{~L}$ container-grown trees when planted into landscape. Note roots were deflected down and around at the position of the $57 \mathrm{~L}$ container. No large roots extend from the trunk to edge of $170 \mathrm{~L}$ root ball.

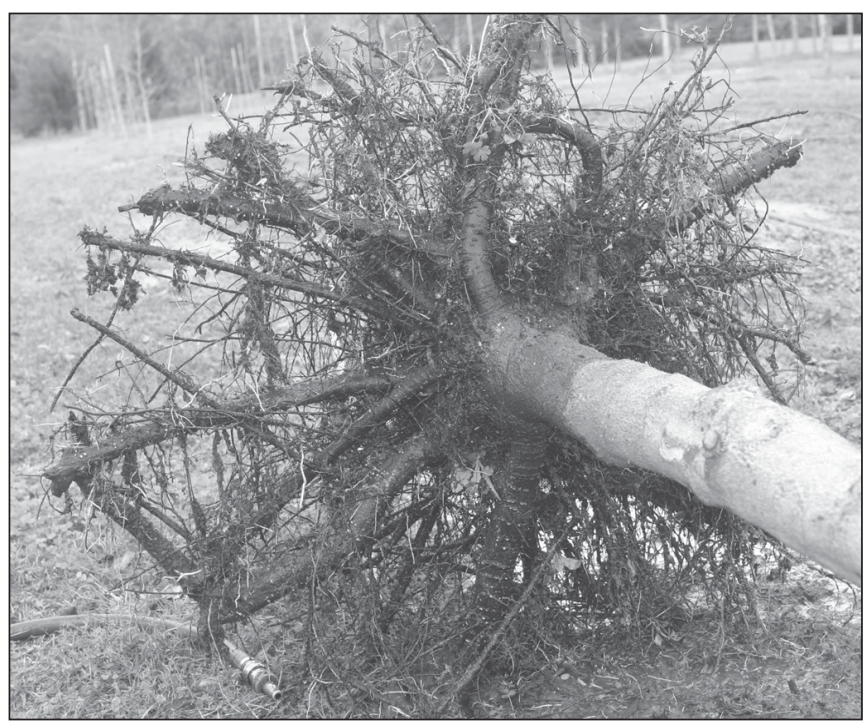

Figure 7. Root system of field-grown tree at planting into landscape showing many roots growing directly from trunk to edge of root ball.

main roots grow quickly into mineral landscape soil. This would allow roots on the lee side close to the trunk to push against stiffer mineral soil in wind events; this may increase stability.

Roots on leeward side are pushed down into soil when wind loaded (Stokes 1999). Large woody roots on trees planted from $170 \mathrm{~L}$ containers pushed against decomposing soilless organic substrate in container root balls when trunks were pulled. Roots close to the trunk first sank into the decomposing root ball on leeward side followed by lifting on windward side. The observed hinge point on the lee side was positioned at either the $3.7 \mathrm{~L}$ or more typically $57 \mathrm{~L}$ container wall depending on the tree. This may have contributed to reduced pulling stress required to tilt trees planted from $170 \mathrm{~L}$ containers compared to trees transplanted from the field (Figure 4). More subsidence in trees planted from containers (Table 1) than trees from the field provides evidence that organic material in container root balls decomposed significantly over the three growing seasons following planting. The study was not designed to decipher the contribution to reduced stability from root deflection and decomposing substrate.

In contrast, roots close to the trunk on trees from the field pushed against stiffer (compared to organic soils, Fraser and Gardiner 1967) mineral soil that comprised the field root ball. Field trees did not appear to sink much on the lee side (this was not measured); instead windward side lifted with leeward hinge point farther away from trunk. Ennos (1995) and Coutts et al. (1999) suggested that more overturning moment is required to tip a tree if the hinge point is farther from the trunk. Perhaps as trees grow larger and woody roots become stiffer, stability on container-grown trees will increase as roots compensate for deformities by growing larger. Past work supports this on trees planted from much smaller containers. For example, Nichols and Alm (1983) found that conifers planted from $5 \mathrm{~cm}$ diameter containers were less stable 7-9 years after planting than naturally regenerated trees, but by 18 years after planting there was no difference. Others have similarly determined that conifers from small containers eventually gained stability comparable to naturally generated trees (Nielson 1998). 
Stability has been associated with shallow roots in the windward direction (Stokes 1995), symmetrical lateral roots (Coutts et al. 1999), tap roots (Danjon et al. 2005), leeward sinker root length (Hayfa et al. 2007), and combinations of these and other attributes on various soil types. There appears to be no consensus on optimum root structure for tree stability. Mickovski and Ennos (2002) showed that root CSA and trunk DBH together accounted for $52 \%$ of overturning moment. Hayfa et al. (2007) found that combinations of root number, root depth, and trunk taper explained up to $80 \%$ or more of variability in trunk bending stress to pull trees to a set angle. In the current study, it was found that $97 \%$ of overturning moment was accounted for by trunk diameter and total root CSA measured just outside original root ball in upper $25 \mathrm{~cm}$ of soil (Equation 3). Root CSA and diameter of largest roots, especially in the windward direction, correlated best with trunk bending stress required to pull trees to 10 degrees tilt from unloaded start position (Table 4). Root size (diameter or CSA) on windward and leeward sides was most correlated with maximum bending stress encountered while pulling to 25 degrees (Table 4); however, wind required to push trees to this extent would exceed $45 \mathrm{~m} \cdot \mathrm{s}^{-1}$. Maximizing root CSA and diameter of roots in the upper $25 \mathrm{~cm}$ soil profile outside of original root ball appears crucial for encouraging stable live oak in this soil type.

The overturning bending moment generated by winching to simulate wind load to uproot trees increases proportionately with 1.6 the power of trunk diameter to as high as 2.9 the power of trunk diameter (Crook and Ennos 1998; Stokes 1999; Mickovski and Ennos 2003; Tanaka and Yagisawa 2009). Overturning bending moment for live oak in the current study (Equation 3) scaled to the 3.4 power of trunk diameter (caliper) but the trunk diameter lower $(0.15 \mathrm{~m})$ on the trunk was measured, which could have contributed to the larger exponent. In contrast, trunk strength scaled to the third power of trunk diameter (Crook and Ennos 1996; Tanaka and Yagisawa 2009). This indicates the trunk on many trees become stronger than the root system as trees age commonly resulting in root failures instead of trunk failures on mature trees.

Roots on trees planted from $57 \mathrm{~L}$ containers responded like trees planted from $170 \mathrm{~L}$ containers except $57 \mathrm{~L}$ trees had larger root diameter $/ \mathrm{cm}^{2}$ trunk CSA (Table 1). Relatively large diameter roots may explain the similarity of $57 \mathrm{~L}$ trees to trees transplanted from the field in bending stress required to tilt trunks to 15 degrees (Figure 4) or more (data not shown). Evidence of this is the importance of large root diameter in resisting maximum overturning (Table 4). Pulling force normalized for trunk CSA (bending stress; Figure 4) required to tilt trees planted from $57 \mathrm{~L}$ containers was similar to trees from $170 \mathrm{~L}$ containers indicating similar stability three growing seasons after planting. There should be tests for more variation in container size, different species, and allow more time after planting before evaluating stability.

This project is limited because it only compared one species grown under one set of conditions in one soil type in one organic substrate in one container type. Production practices including type of container, time in container, irrigation, fertilization, root pruning, and other practices influence root morphology inside the root ball, and these need to be studied in order to better understand attributes of stable trees in urban environments.
Acknowledgments: Thanks go to the TREE Fund and GreatSouthernTreeConference.org for partial funding.

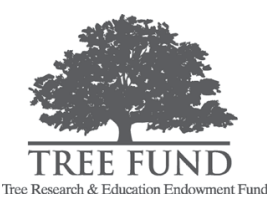

\section{LITERATURE CITED}

Anonymous. 2004. American standard for nursery stock. American National Standards Institute (ANSI Z60.1). American Association of Nurserymen. Washington, D.C.

Blanusa, T., E. Papadogiannakis, R. Tanner, and R.W.F. Cameron. 2007 Root pruning as a means to encourage root growth in two ornamental shrubs, Buddleja davidii 'Summer Beauty' and Cistus 'Snow Fire'. Journal Horticultural Sciences and biotechnology 82:521-528.

Burdett, A.N. 1978. Control of root morphologenesis for improved mechanical stability in container-grown lodgepole pine. Canadian Journal of Forest Research 8:483-486.

Coutts, M.P. 1983. Development of the structural root system of Sitka spruce. Forestry 56:1-16.

Coutts, M.P. 1986. Components of tree stability in Sitka spruce on peaty gley soil. Forestry 59:173-197.

Coutts, M.P., C.C.N. Nielson, and B.C. Nicoll. 1999. The development of symmetry, rigidity, and anchorage in the structural root system of conifers. Plant and Soil 217:1-15.

Crook, M.J., and A.R. Ennos. 1998. The increase in anchorage with tree size of the tropical tap-rooted tree Mallotus wrayi, King (Euphorbiaceae). Annals of Botany 82:291-296.

Danjon F., T. Fourcaud, and D. Bert. 2005. Root architecture and windfirmness of mature Pinus pinaster. New Phytology 168:387-400.

Dunn, G.M., J.R. Huth, and M.J. Lewty. 1997. Coating nursery containers with copper carbonate improves root morphology of five native Australian tree species used in agroforestry systems. Agroforestry Systems 37:143-155.

Duryea, M.L., E. Kampf, and R.C. Littell. 2007. Hurricanes and the urban forest: I. Effects on southeastern United States coastal plain species. Arboriculture \& Urban Forestry 33:83-97.

Ennos, A.R. 1995. Development of buttress in rainforest trees: the influence of mechanical stress. In: M.P. Coutts and J. Grace (Eds.). Wind and trees. Cambridge Univ. Press Cambridge. pp. 293-301.

Fourcaud, T., J. Ji, Z. Zhang, and A. Stokes. 2007. Understanding the impact of root morphology on overturning mechanisms: A modeling approach. Annals of Botany 100:1093.

Fraser, A.I., and J.B.H. Gardiner. 1967. Rooting and stability in Sitka spruce. Forestry Commission Bulletin 40, HMS, London.

Gilman, E.F., I.A. Leone, and F.B. Flower. 1987. Effect of soil compaction and oxygen content on vertical and horizontal roots distribution. Journal of Environmental Horticulture 5:33-36.

Gilman, E.F., and M.E. Kane. 1991. Growth dynamics following planting of cultivars of Juniperus chinensis. Journal American Society Horticulture Science 116:637-641.

Gilman, E.F., T.H. Yeager, and D. Weigle. 1996. Fertilizer, irrigation and root ball slicing affects Burford holly growth after planting. Journal of Environmental Horticulture 14:105-110.

Gilman, E.F., and C. Harchick. 2008. Planting depth in containers affects root form and tree quality. Journal of Environmental Horticulture 26:129-134.

Gilman, E.F., C. Harchick, and C. Wiese. 2008. Pruning roots affects tree quality in container-grown oaks. Journal of Environmental Horticulture 27:7-11. 
Gilman, E.F., M. Paz, and C. Harchick. 2010a. Root ball shaving improves root systems on seven species in containers. Journal Environmental Horticulture 28:13-18.

Gilman, E.F., C. Harchick, and M. Paz. 2010b. Effect of tree size, root pruning and production method on establishment of Quercus virginiana. Arboriculture \& Urban Forestry 36:183-190.

Gilman, E.F., C. Harchick, and M. Paz. 2010c. Effect of container type on root form of red maple. Journal of Environmental Horticulture 28:1-7.

Halter, M.R., C.P. Chanway, and G.J. Harper. 1993. Growth reduction and root deformation of containerized lodgepole pine saplings 11 years after planting. Forest Ecological Management 56:131-146.

Harrington, T.B., and K.D. Howell. 1998. Planting cost, survival and growth one to three years after establishing loblolly pine seedlings with straight, deformed, or pruned taproots. New Forests 15:193-204.

Harris, J.R., and E.F. Gilman. 1993. Production method affects growth and post-transplant establishment of 'East Palatka' holly. Journal American Society Horticulture Science 118:194-200.

Hayfa, K., A. Stokes, F. Danjon, K. Gouskou, and F. Lagane. 2007. Is it possible to manipulate root anchorage in young trees? Plant Soil 294:87-102.

Krasowski, M.J., and J.N. Owens. 2000. Morphological and physical attributes of root systems and seedlings growth in three different Picea glauca reforestation stock. Canadian Journal of Forest Research 30:1669-1681.

Lindstrom, A., and G. Rune. 1999. Root deformation in plantations on container-grown Scots pine trees: effects on root growth, tree stability and stem straightness. Plant and Soil 217:29-37.

Lyford, W.H., and B.F. Wilson. 1964. Development of the root system of Acer rubrum L. Harvard Forest Paper 10. Harvard University, Petersham, MA. 17 p.

Marshall, M.D., and E.F. Gilman. 1998. Production methods and irrigation affect root morphology of live oak. Journal of Environmental Horticulture 15:84-87.

Mickovski, S.B., and R. Ennos. 2002. A morphological and mechanical study of the root systems of suppressed crown Scots pine Pinus sylvestris. Trees 16:274-280.

Mickovski, S.B., and R. Ennos. 2003. Anchorage and asymmetry in the root system of Pinus peuce. Silva Fennica 37:161-173.

Nichols, T.J., and A.A. Alm. 1983. Root development of containerreared, nursery-growth, and naturally regenerated pine seedlings. Canadian Journal of Forest Research 13:239-245.

Nielson, C.N. 1998. Root development of bare rooted seedlings after field establishment and consequences for wind stability. In: C. Almqvist (Ed.). Root development and stability. Conf. held at Garpenberg, Sweden, 30 Sept-1 Oct 1997. The Forest Research Institution of Sweden Report No. 7. pp. 66-71.

Ortega, U., J. Majada, A. Mena-Petite, J. Sanchez-Zabala, N. RodriguezItturrizar, K. Txarterina, J. Azpitarte, and M. Duñabeitia. 2006. Field performance of Pinus radiata D. Don produced in nursery with different types of containers. New Forests 31:97-112.

Robert, J.A., and B.S. Lindgren. 2006. Relationships between root form and growth, stability, and mortality in planted versus naturally regenerated lodgepole pine in north-central British Columbia. Canadian Journal of Forest Research 36:2642-2653.

South, D.B., and R.G. Mitchell. 2005. A root-bound index for containergrown Pines. In: S.J. Colombo (Ed.). The Thin Green Line: A symposium on the state-of-the-art in reforestation. Forest Research Information Paper No. 160. Ontario Forest Research Institute. Sault Ste. Marie, Ontario. pp. 88-93.
Sundstrom, E., and M. Keane. 1999. Root architecture, early development and basal sweep in containerized and bare-root Douglas-fir (Pseudotsuga menziesii). Plant and Soil 217:65-78.

Stokes, A. 1999. Strain distribution during anchorage failure of Pinus pinaster Ait. at different ages and tree growth response to windinduced root movement. Plant and Soil 217:17-27.

Stokes A., A.H. Fitter, and M.P. Coutts. 1995. Response of young trees to wind: effects on root growth. In: M.P. Coutts and J. Grace (Eds.). Wind and Trees. pp. 264-275. Cambridge University Press, Cambridge, UK.

Stout, B.B. 1956. Studies of the root systems of deciduous trees. Black Forest Bulletin 15. Cornwall-on-the-Hudson, NY: Harvard University $45 \mathrm{p}$.

Tanaka, N., and J. Yagisawa. 2009. Effects of tree characteristics and substrate condition on critical breaking moment of trees due to heavy flooding. Landscape and Ecological Engineering 5:59-70.

Edward F. Gilman (corresponding author)

Professor

Environmental Horticulture Department

University of Florida

Gainesville, FL, U.S.

Forrest J. Masters

Assistant Professor

Civil and Coastal Engineering Department

University of Florida

Gainesville, FL, U.S. 
Résumé. Cette recherche visait à évaluer l'impact de trancher la périphérie externe des mottes de racines d'arbres produits en contenant, celui de la dimension initiale de l'arbre lors de la plantation et celui de la composition de la motte de terre, le tout par rapport à la stabilité post-plantation des arbres face à une simulation de vent de tempête. Cent vingt chênes de Virginie Cathedral ${ }^{\circledR}$ ont été plantés en mars 2005. Trente arbres produits en champs ont été transplantés et 60 arbres de dimension similaire produits en contenant de $170 \mathrm{~L}$ ont été plantés. Les mottes de racines de 30 sujets produits en contenant ont été tranchées préalablement à leur plantation. Trente arbres plus petits produits en contenant de $57 \mathrm{~L}$ ont été plantés sans tranchage préalable des mottes. Les arbres ont été tirés au moyen d'un treuil électrique et soufflé au moyen d'un simulateur d'ouragan en 2007. Le tranchage des mottes de racines n'a eu aucun effet sur la croissance des racines, le moment de flexion ainsi que le stress de flexion. Un stress de flexion plus important a été requis pour tirer les arbres produits en champs par rapport à ceux produits en contenant (peu importe la taille du contenant de production). La production d'arbres en contenant sur une période de trois ans avant leur mise en terre a eu pour effet de modifier la morphologie des racines comparativement aux arbres produits en champs, ce qui résultait en une perte de stabilité. Les arbres produits dans des contenants plus petit étaient aussi stables que ceux produits dans des plus gros contenants. La superficie de la coupe transversale des racines qui font face au vent est le facteur de corrélation le plus important par rapport au stress de flexion requis pour incliner l'arbre au moyen d'un treuil et d'un câble. Le moment de flexion s'échelonnait à une force de 3,4 en regard du diamètre du tronc.

Zusammenfassung. Diese Forschung zielt darauf, den Einfluss von Einschnitten in den äußeren Rand eines Container-Wurzelballens zu bewerten, die Baumgröße bei der Pflanzung und die Wurzelballenzusammensetzung bei einem simulierten Sturmereignis. Einhundertzwanzig Lebenseichen wurden im März 2005 gepflanzt. Dreisig feldgezogene Bäume wurden verpflanzt und sechzig Bäume in ähnlicher Größe aus 1701 Containern wurden ausgepflanzt. Die Wurzelballen von dreisig Containern wurden vor der Pflanzung eingeschnitten. Dreisig schmalere Bäume aus 571 Containern wurden ohne Einschnitte gepflanzt. Die
Bäume wurden 2007 mit einer elektrischen Winde rausgezogen und in einem Windsimulator Sturmbedingungen ausgesetzt. Das Einschneiden des Wurzelballens hatte keinen Einfluss auf das Wurzelwachstum, das Biegemomentum oder den Biegestress. Um die feldgezogenen Bäume herauszuziehen bedurfte es mehr Zugstress als bei den containergezogenen Bäume, egal, welche Größe. Das Ziehen von Bäumen in Containern für drei Jahre vor dem Auspflanzen veränderte die Wurzelmorphologie im Vergleich zu den feldgezogengen Bäumen, welche mit verminderter Stabilität reagierten. Bäume aus kleineren Containern waren ebenso stabil wie Bäume aus größeren Containern. Die Wurzelquerschnittfläche zum Wind korrelierte mit dem aufzuwendbaren Biegemoment, um die Bäume mit einer Winde und Kabel herauszuziehen. Das Biegemoment lag bei 3,4facher Kraft zum Stammdurchmesser

Resumen. La investigación permitió evaluar el impacto de cortar el límite exterior de las bolas de raíces del contenedor, tamaño inicial en la plantación, y composición de la bola de raíces en la estabilidad de árboles post-plantación en una tormenta simulada de viento. Se plantaron 120 encinos Cathedral Oak® en marzo de 2005. Fueron trasplantados 30 árboles crecidos en el terreno, y 60 árboles de tamaño similar fueron plantados de contenedores de 170 L. Los lados de las bolas de raíces en 30 contenedores fueron cortados antes de la plantación. Treinta árboles pequeños de contenedores de $57 \mathrm{~L}$ fueron plantados sin cortar. Los árboles fueron halados con una grúa eléctrica y soplados con un simulador de huracanes en 2007. Cortar la bola de raíces no impactó el crecimiento de la raíz, momento de doblamiento o estrés de doblamiento. Se requirió más estrés de doblamiento para halar a los árboles crecidos en terreno que a los árboles plantados de contenedores de cualquier tamaño. Los árboles crecidos en contenedor por tres años antes de llevar al paisaje cambiaron la morfología de la raíz comparados a los árboles crecidos en el terreno, los cuales correspondieron a estabilidad reducida. Los árboles plantados de contenedores pequeños fueron tan estables como los de contenedores más grandes. El área trasversal de la raíz a barlovento correlacionado con el estrés de doblamiento requirió de una grúa y cable. El momento de doblamiento escaló a la potencia de 3.4 el diámetro del tronco. 